\title{
Teses sobre Karl Marx
}

FER NANDO HADDAD

S SOCIALISTAS, até hoje, incidiram no erro de acreditar que o desenvolvimento das forças produtivas, sob o capitalismo, faria explodir as relaçóes de produção que o configuram, quando na verdade, ao contrário das antigas formaçóes sociais, o capitalismo se vale desse desenvolvimento para se legitimar, sendo que a dialética entre as forças produtivas e as flexíveis relaçóes capitalistas de produção se desdobra de uma maneira historicamente nova, a um só tempo dinâmica e estaticamente.

Os socialistas se valem das crises do capitalismo, expressão do seu caráter inerentemente contraditório e irracional, para afirmar seu ponto de vista. Não obstante, a questão sobre qual será a crise final desse sistema é uma questão político-prática e não econômico-teórica.

III

Os socialistas querem erradicar do mundo a pobreza de espírito. Tomam-na como produto direto das atuais condiçôes materiais de existência. $O$ movimento socialista funda-se no materialismo, mas entendido como crítica social, tendente a sua consumação.

IV

O socialismo não deve ser tomado como um fim, como telos, mas como um novo começo, como reconciliação entre homem e natureza que não reivindica um passado longínquo, pois essa reconciliação se dá num outro plano, num patamar jamais atingido.

\section{V}

O socialismo não deve ser tomado como uma ordem fundada em valores por ele criados. O socialismo é o desentrave definitivo do processo de individuação, obstruído pela sociedade de classes. $O$ socialismo é a exuberância dos indivíduos de uma vez por todas libertos de valores prescritos, unidos solidariamente pelos laços de justiça, exclusivamente. 
O socialismo é igualmente o desentrave do processo de formaçáo de uma comunidade internacional que preserva as diferenças entre os povos, e que faz delas o testemunho da riqueza do enfim realizado gênero humano.

VII

O socialismo é o reino da justiça onde se exerce a liberdade.

\section{VIII}

Os socialistas pretenderam transformar o mundo; cabe, porém, transformar os homens, isto é, motivá-los para aquela transformaçăo. $O$ socialismo depende de um salto psicoterapêutico para além da dominaçáo orquestrada democraticamente na esfera pública.

IX

O socialismo não é um desdobramento lógico do capitalismo, embora seja uma possibilidade objetiva. O lógico é táo-somente o histórico que se impôs, por vezes ilogicamente. $O$ socialismo é a saída talvez ilógica de um mundo certamente irracional.

\section{$\mathbf{X}$}

O socialismo é a superação prática da metafísica realmente existente. Como a dialética é tão-somente o fruto do esforço mental de compreensão da fantasmagoria reinante, o advento do socialismo implicará sua obsolescência.

\section{$\mathbf{X I}$}

Até lá, os socialistas devem reinterpretar continuamente o mundo social para uma práxis transformadora sempre renovada.

Fernando Haddad é professor do Departamento de Ciência Política da Faculdade de Filosofia, Letras e Ciências Humanas da Universidade de São Paulo. 